DOI https://doi.org/10.36059/978-966-397-172-8/1-23

\title{
TAORMINA AND TAURIDA \\ (ABOUT SICILIAN AWARD OBTAINED BY ANNA AKHMATOVA-HORENKO)
}

\section{Kazarin V. P.}

\section{INTRODUCTION}

She was a celebrity of 1910s - 1920s. But then, after a severaldecade-long period of non-publication, she became half-forgotten. She was still highly rated but (as they said) "in narrow circles". She was attained (in her own words) and publicly anathematized by a special decree issued by the Central Committee of the All-Union Communist Party of Bolsheviks in $1946^{1}$. And yet she - Anna Andreevna AkhmatovaHorenko (1889-1966) - lived up to see her public and literary resuscitation.Here is how Irina Nikolaevna Punina, Akhmatova's assistant andNikolai Nikolaevich Punin's daughter (Anna Akhmatova's third husband), who had a fellow feeling for her, writes about: «B 1954-м году впервые за много лет - Анна Андреевна выехала за пределы Москвы-Ленинграда, вместе с Аней Каминской она побывала в Таллине, и это был первый симптом пробуждения. Постепенно Ахматова получает возможность работать и печататься, ей дают всё больше и больше заказов на переводы корейской, китайской, болгарской (добавим: и украинской. - Aвт.) поэзии; публикуются её собственные стихи в периодических изданиях. Наконец, в 1958-м году вышла первая после страшного постановления ЦК ВКП(б) 1946 г. маленькая книжка стихов Ахматовой. В 1961-м - следующая. $<\ldots>$ В 1960-е годы стихи Ахматовой были переведены и изданы почти на всех европейских языках».

It was Anna Akhmatova's leaving abroad that caused the most difficulties. But let's keep on I. N. Punina's story: A. A. «многократно приглашали на различные форумы», но «Союз писателей (СССР. Авт.), как правило, даже не уведомлял об этом Ахматову»². Finally,

\footnotetext{
${ }^{1}$ Казарин В. П., Новикова М. А. «... Ровно десять лет ходила / Под наганом...»: (А. А. АхматоваГоренко и сэр Исайя Бёрлин) // Вчені записки Таврійського національного університету імені В. І. Вернадського. Серія: «Філологія. Соціальні комунікації». Т. 29 (68). № 2. - Київ: Гельветика, 2018. - C. 201-213.

2 Пунина И. Н. Анна Ахматова в Италии // La Pietroburgo di Anna Achmatova. - Bologna: Grafis Edizion, 1996. - P. 54-64.
} 
in the summer of 1964, Secretary General of the European Community of Writers, Giancarlo Vigorelli, visited Leningrad. He saw Akhmatova in Komarovo and personally gave her an invitation to the next community congress, which was to be held in Sicily. Anna Akhmatova had to obtain the Etna-Taormina International Italian Literary Prize there ${ }^{3}$.

\section{Italy, Sicily, Taormina}

The first - after a half-century break - Anna Akhmatova's leaving abroad. The first anthological book of her poems in translation of the Nobel laureate, Salvatore Quasimodo. The first foreign literary prize. All these events are deeply symbolic. We will comment them and move on to the Italian location.

Why are the events of 1964 symbolic for Akhmatova? Firstly, the concepts of "self-non-self" got strengthened, but also inverted. The border crossing (according to Akhmatova's feelings and her companion's memories) didn't prove to be a parting with Leningrad, but a meeting with Rome, then with Sicily and Taormina. Truly speaking, Akhmatova dreamed most to see Venice, about which she had been keeping memories since her first travel to Italy (1912). That wasn't going to happen. They were going through the city at night, in dense fog.

The second finding: Italy of the "second arrival" was not everywhere "her own space" for Akhmatova. The bell ringing and pre-Christmas window decoration in Catania, the capital of Sicily, reminded Akhmatova her pre-Christmas childhood. But, in the same city, a huge administrative building in the central square with a pompous statue in front looked as "a stranger" - (it reminds the American Statue of Liberty, writes I. N. Punina"; for "Soviet" guests, the association could be different). "Sicily's spring in December" turned out to be "her good fairy tale": lemons and oranges in trees along the road, bright green grass and cacti in blossom ("higher than two-story buildings"). Luxuriously tasteless rooms in the capital's hotels stroke "as strange". Having been turned into a hotel, the Dominican monastery in Taormina looked "her own" with "rooms cells", old wooden beds and floor-to-ceiling windows overlooking the garden. Cheerful poets and Italian journalists came to Akhmatova to get introduced "as friends"; she gave them a treat of a black bread with vodka "as to friends"; and the conversation was flowing beyond midnight

${ }^{3}$ [Б.а.] Русские писатели - лауреаты итальянских литературных премий. [Электронный ресурс]. Режим доступа: http:// https://www.bfrz.ru/?mod=static\&id=655.

${ }^{4}$ Пунина И. Н. Анна Ахматова в Италии // LaPietroburgodiAnnaAchmatova. - Bologna: GrafisEdizion, 1996. - P. 54-64. 
"as between friends". The official meetings, conference rooms, marble and bronze, "floodlights" and media sensationalism were "strange". Tvardowsky was "her own": he himself was helping the laureate to prepare her presentation at the award ceremony and reverently listened to her recitation of poems about the Muse and about Dante's Pages of Hell. I.N. Punina: «Я не помню такого сосредоточенного внимания к стихам даже среди самых горячих поклонников Ахматовой» ${ }^{5}$

The officials from the Writers' Union had been "strangers" and still were.

To sum up: the poetess took as "her own" both chronologically distant (childhood and youth memories, when her Motherland and Western Europe did not yet look like different planets), and recent (when she perceived the atmosphere of foreign countries and the "capital on the Neva" as already dissimilar, but still mutually "translatable”). Everything that had a big distance from one another looked like "strange" making Akhmatova of 1964, a stranger both in Italy and "at home".

She was unlikely to forget the powerful image of Duce's fascist Italy in the verses of Osip Mandelstam from the 1930s: «<..> И над Римом диктатора-выродка / Подбородок тяжёлый висит» But she could not forget the black "Maroussia" (paddy wagons) at the night entrances to Leningrad houses during the Stalinist era. The joy of the Taormina meeting for both sides, Russian and Italian, was mutual. It was a common joy of liberation ${ }^{6}$.

But what did Akhmatova see in Sicily? Through the eyes of history, not only decades, but also centuries (or millennia)? What bridges were drawn between this Great History - and the personal biography of the Taormina laureate?

It is immediately obvious: one name sounds over both stories Taurus. The poetess' childhood and youth are overshadowed by the Crimea: ancient Taurida and Tauric Chersonesos. Akhmatova called herself "the last Chersonesos dweller". She spent more than one summer in Taurida, fleeing from a family ailment - consumption.

Then she studied at Yevpatoriya gymnasium of the Taurida province (home-schoolingfor health reasons - and passed exams externally) ${ }^{7}$.

\footnotetext{
${ }^{5}$ Пунина И. Н. Анна Ахматова в Италии // La Pietroburgo di Anna Achmatova. - Bologna: Grafis Edizion, 1996. - P. 54-64.

${ }^{6}$ A lot of writers who met Akhmatova in Italy and / or translated her poems took part in the Resistance during the Second World War.См.: Потапова 3. М. Литература Сопротивления: Италия // Литературный энциклопедический словарь (далее сокр. ЛЭС). - Москва: Советская энциклопедия, 1987. - С. 412.

${ }^{7}$ For details, refer to: Казарин В. П., Новикова М. А. Анна Ахматова и Херсонес: что сказали поэту «смуглые главы» храма? // Сайт «КРУ УНБ имени И. Я. Франко» (franco.crimea.ua). - 02.06.2014.
} 
Sicilian Taormina is located on the slope and at the foot of the Taurus Mountains (Monte Tauro, $206 \mathrm{~m}$ above sea level). The mountain, of course, is also Sicilian. But the ancient Greeks "measured" the location of Tauro from Asia Minor rather than from Sicily (like modern geophysicists). Tauro is not an isolated mountain, it is part of a giant mountain range that begins at the Holy Cape (modern Turkish Helidoni Cape). Then one Tauro spur goes to Palestine, another to Armenia, and the third - through the North Caucasus and the mountains of Crimea to the Balkans and from there to the Southern Italy and Sicily ${ }^{8}$

All derivatives come from this Tauro: the name of the (Tauri tribe ${ }^{9}$ ), the goddess Artemis of Tauride's name - Tauropolos $^{10}$ ) and the city name. The Hellenes called it Tauromenion, the Romans - Tauromenium, the Sicilians - Taurmina, the Italians - Taormina ${ }^{11}$.

Akhmatova's cheerful guests from Taormina were likely not only to sing songs, read poetry, eat exotic black bread and drink exotic vodka. (Anna Andreevna got all this stuff from friends before a foreign trip. Years passed but the traditional souvenirs of the "Soviet" tourist didn't change.)

Patriotic Sicilians probably told Akhmatova their homeland's history. They could start with the fact that Sicily's original population had come to the Western Mediterranean before the Indo-Europeans-Italici, the future Romans. Then Sicily was colonized by the Phoenicians who had fled from the Assyrians, then by the Palestinian Philistines, the inhabitants of the Eastern Mediterranean. Sailed awayfrom internal "civilian storms", the Hellenes took over Sicily. They established a settlement called Tauromenion in the middle of the $4^{\text {th }}$ century BC. The storms, however, caught upwith them there. Bloody internal strife lasted until the end of the $3^{\text {rd }}$ century BC and helped the Romans capture the city.

The Romans also brought little peace. In the middle of the $2^{\text {nd }}$ century BC Sicily was shocked by the First Slave Revolt, then, at the end of the century,the Second Revolt happened. The slaves even established their state in Sicily, but eventually they were defeated and slaughtered. However, the "civil storms" went on. The war between Octavian and Pompey, two of the three Roman Republic co-rulers, swept through Tauromenium. Octavian prevailed and became Emperor Augustus but the

${ }^{8}$ [Б.а.] Taurus // Словарь классических древностей по Любкеру. Пер. с немецкого. Под ред. Ф. Зелинского и др. СПб., 1885. - 1552 с. - С. 1346. (Далее сокращенно: Любкер).

${ }^{9}$ [Б.а.] Tauri // Любкер, с. 1345.

${ }^{10}$ [Б.а.] Tauropolos, Arthemis // Любкер, с. 164.

11 [Б.а.] Tauromenium // Любкер, с. 1346. 
city located on his way was completely destroyed. Having been a large center of shopping, craft and culture (the ancient theater in Taormina was designed for almost 10,000 spectators), the city turned into a small village. It had enlarged its population to the previous number of inhabitants only by 2004 (10 863 people) $)^{12}$.

The time went by. In the beginning of the $10^{\text {th }}$ century A.D., after a two-year siege, the Arabs captured the Byzantine Taormina. For the second time, the Arabs took the city half a century later. The ancient city center was destroyed, a new Arabian center was built on the outskirts. The city got a new name of Al Moesiain honor of Caliph Musa.

In the $11^{\text {th }}$ century, the Normansrecaptured the city from the Arabs"Saracens". It was given the original name. Gradually they built up the Christian holy places: the Cathedral of St. Nicholas (Dom San Nicolo, $15^{\text {th }}$ century), the church named after St. Augustine, Bishop of Hippo (San Agostino, $15^{\text {th }}$ century), St. Pancrates, bishop, patron of the city (San Pancrates, $16^{\text {th }}$ century), and others. Particularly revered by the Taormins is the church Madonna della Rocca, $17^{\text {th }}$ century) ${ }^{13}$ These holy places will be considered below.

\section{Petersburg, Crimea, Chersonesos}

Even this - forcedly brief - "historical digression" of the Sicilian city, superimposed on our poetess' life geography, makes it clear how many intersections they have. Let's develop this idea further.

It seems to Akhmatova that Petersburg-Petrograd-Leningrad cannot be compared with Taormina in historical and cultural context. But that is not exactly true. The Neva banks and the Baltic seaside like Sicily and Taormina had their own "prehistoric", legendary past. Which Petersburgers do not remember the legend about Peter I who met the "Chukhonsky" magician-shaman? There was on Vasilievsky Island (St. Petersburg's future address of Akhmatova's close acquaintance - poet Joseph Brodsky), under a mighty oak tree (an oak considered a sacred tree by all Indo-Europeans, not only by them) where the tsar (according to the legend) met a local priest near the Neva curved seashore.

The ruler was looking for a place to found a city «будет город заложен / на зло надменному соседу», that is, the Swedes. The magician shook his head and pointed to the blackened mark on the

\footnotetext{
${ }^{12}$ About Taormina, see: https://www.britannica.com/place/Taormina; https://ru.wikipedia.org/ wiki/Таормина.

${ }^{13}$ Новикова М. А. Пушкинский космос: Языческая и христианская традиции в творчестве Пушкина (Серия «Пушкин в ХХ веке». Вып. 1.). - Москва: Наследие, 1995. - 353 с.
} 
oak bark - the upper boundary of the annual Neva floods. Peter ordered the oak to be cut down, and the city to be laid down. He thought he was acting (according to Pushkin) "to spite" Russia's political rival in the Baltic area.

It turned out that Peter himself "pawned" the history of St. Petersburg for spite - contrary to the "God's dictate" (again according to Pushkin), contrary to the natural environment ${ }^{14}$.

Taormina was built and settled by the Greeks. It is located on Taurus plateau (a mountain with volcanic, subaqueous and reef past). The city is located near the active volcano Etna. The Taormina dwellers wanted to find a better place to live but decided to settle there. Their former village on the island of Naxos ${ }^{15}$ was captured and destroyed at the end of the 5th century BC., its inhabitants were expelled.

Before the ancient Greeks, we remember, there were even more ancient inhabitants - the Sicels. This tribe's name is kept forever in the island's name - Sicily. All subsequent centuries, with each slave revolt or raids made by other tribes, the natives - Sicels' descendants - took the side of the "strangers". This went on until the Greeks and Sicels merged, turning into the Sicilians.

The competition between an "alien” civilization and "native” nature ${ }^{16}$ brings Taormina closer both to Petersburg and to Taurida. In the $3^{\text {rd }}$ Century B.C. the Taormina inhabitants built a theater (see the theater photo $^{17}$ ) by carving it right in the sacred mountain Taurus, removing (according to modern estimates) about $100,000 \mathrm{~m} 3$ of limestone rock. Anna Andreyevna was aware of a similar case in Taurida.

14 Новикова М. А. Пушкинский космос: Языческая и христианская традиции в творчестве Пушкина (Серия «Пушкин в ХХ веке». Вып. 1.). - Москва: Наследие, 1995. - С. 47-66, 287-294.

15 [Б.а.] Naxos // Любкер, с. 909, 1245.

16 The duel of nature and civilization, unfolding in the landscapes of Sicily, was sensitively caught by the French poet Jose Maria de Heredia (1842-1905). His book Trophies contains a chapter entitled Greece and Sicily; there is also a sonnet Antique Medal dedicated to Sicily. The key message of these verses is the sensory luxury of nature (and the moments of history as the eternal Present) and, in contrast, the decrepit memory of history as the eternal Past). Back in 1920-23, Trophies was translated by Akhmatova's friend Mikhail Leonidovich Lozinsky (together with his students). In the commentary to the above-mentioned sonnet, he briefly set forth the history of Sicily, starting from the Phoenicians and Carthaginians, moving to the Greeks, then the Romans from 214 BC., the Vandals - since 440 A.D., the Goths from 493 A.D., the Byzantines from 535 A.D., the Saracens from the $9^{\text {th }}$ century, the Normans from the $11^{\text {th }}$ century, Anjuans in the $13^{\text {th }}$ century.

См.: [Лозинский М. Л. Комментарий] // Багровое светило. Стихи зарубежных поэтов в переводе Михаила Лозинского. (Серия «Мастера поэтического перевода». Вып. 17). - Москва: Прогресс, 1974. 216 c. - C. 211.

${ }^{17}$ The images used in our article (landscapes of Taormina, a bust of A. A. Akhmatova-Horenko, the Etna-Taormina Prize awarding, etc.), see on the websites:https://www.britannica.com/place/ Taormina; https://ru.wikipedia.org/wiki/Tаормина; http://www.bfrz.ru/?mod=static\&id=655; https://www.russianartandculture.com/news-anna-akhmatovas-monument-opens-in-sicily. 
In 1929, she again was getting treatment in the Crimea, this time in the southern coastal village of Gaspra, near the former Roman fortress Haraks $^{18}$. Gaspra is located near Alupka, famous for its palace and park, which were once the estate of Count Mikhail Vorontsov.

The locals or cultural figures who were visiting the island could tell Akhmatova how in the 19th century, while creating the Alupka landscape park, they blew up and torn down a huge part of the granite rock, where this park was to be established. And this rock with ledges going up, there, on the top, is called the Mount of the Cross, that is, the Sacred Mountain ${ }^{19}$.

Let's remember the Sacred Cape - the beginning of the Taurus Mountains. The Taormina Theater could remind our poetess the events happened in her Crimean period: the years that she spent in Tauric Chersonesos. If the theater is the pride of Taormina, then the Chersonesos antique theater is the only one on the territory of former Soviet Union.

Chersonesos and Taormina are strikingly similar by their landscapes and history. They both had the centers of Hellenic civilization that were ringed by more archaic "barbarians". Chersonesos was surrounded by Taurus, then the Scythians, then the Sarmatians. Taormina was flanked by the Sicels and the Sikani. Both cities were passed down from Hellas to Rome, from Rome to Byzantium, from Byzantium to the Eastern rule: Chersonesos to the Crimean Khanate, Taormina to the Arab Emirates ${ }^{20}$.

There is also a second architectural complex that closely echoes Taurida andTaormina. In the list of Taormina temples, we have already mentioned the Church Madonna della Rocco). The Crimea has a similar holy site - Bakhchisaray Assumption Cave Monastery. Mother of God icon is literally placed in the rock - above the stairs heading to the cave temple and the monastic cells ${ }^{21}$ (see below).

In connection with Bakhchisaray, it is appropriate to recall another "thing in common". In the autumn of 1916 Akhmatova came in Bakhchisaray from Sevastopol for a week. There, she saw a poet and philologist, a faithful friend and her admirer - Nikolai Vladimirovich

${ }^{18}$ О Гаспре и Хараксе см.: [Б.а.] Всё о Крыме: Справочно-информационное издание / Под общ. ред. Д. В. Омельчука. - Харьков: Каравелла, 1999. - С. 215-216.

${ }^{19}$ Галиченко А. А. Алупка: Дворец и парк . - Киев: Мистецтво, 1992. - 240 с.

${ }^{20}$ Крым: Православные святыни: Путеводитель / Составитель Е. М. Литвинова. - Симферополь: Рубин, 2003. - С. 339-356.

21 Казарин В. П., Новикова М. А. Стихотворение А. А. Ахматовой «Вновь подарен мне дремотой...»: (Опыты реального и поэтологического комментирования). Публикация 1 // Анна Ахматова: эпоха, судьба, творчество: Крымский Ахматовский научный сборник. Выпуск 10. Симферополь: Крымский Архив, 2012. - С. 60-72; Публикация 2 // Сайт «Анна Ахматова: «Ты выдумал меня...»» (akhmatova.org). - 08.05.2013; Публикация 3 // Сайт «Бахчисарайский историкокультурный заповедник» (bikz.org). - 06.06.2013 
Nedobrovo. Like her, he suffered from consumption; like her, he came to the Crimea to be treated; like her, he will soon be covered by the ninth wave of revolution, red terror, hunger - and (in contrast to her) sudden death.

In Bakhchisaray, they will say goodbye forever on the "steps" of the stairs. It is one of the many stairs of that time that allowed residents of the Crimean Tatar capital located at the bottom of a deep valley to climb up the steep slopes to grassy pastures. And it was Bakhchisaray and this "parting in Italy" (a series of blissful starlit nights and a mournful parting) that Akhmatova will remember and write about while travelling to Taormina: «Подъезжаем к Риму. Всё розово-ало. Похоже на мой последний незабвенный Крым 1916 года, когда я ехала из Бахчисрая в Севастополь, простившись навсегда с Н. В. Н<едоброво >» ${ }^{22}$.

It is symbolic that the stairs will accompany the poetess in the rocky Sicily. While travelling around Italy, Akhmatova could not fail to notice the common things between Taurida and Taormina, the Black Sea and the Mediterranean.

\section{Award}

The award given to Akhmatova in Sicily has its own story and its own notable nominees.

The top list of literary prizes in Europe of that time is headed, of course, by the Swedish Nobel Prize ${ }^{23}$. Akhmatova was dreaming about it during the last years of her life. She dreamed, was nominated, but did not receive this award ${ }^{24}$. Anna Akhmatova-Horenko, who celebrated her 75th birthday in 1964, received the national and international prize of the Sicilian city - Etna-Taormina award. It didn't get on the "Soviet" list of prestigious foreign awards of that time ${ }^{25}$. This could mean that the "Soviet" reference books took the prize as either too "aesthetic", or too "regional”, or too "local”. "Regional” - that is, just for Sicily. "Local” that is, established by writers, poets, and critics rather than by state or academic institutions.

In 1951 Umberto Saba became the first laureate of Etna Taormina award (1883-1957). The following years and under the new contest terms the award had to to be given to two contestants. One of them - an Italian

\footnotetext{
${ }^{22}$ Пунина И. Н. Анна Ахматова в Италии // La Pietroburgo di Anna Achmatova. - Bologna: Grafis Edizion, 1996. - P. 800.

${ }^{23}$ Гиленсон Б. А. [Нобелевская премия] // ЛЭС, с. 303.

${ }^{24}$ Найман А. Г. Рассказы об Анне Ахматовой // А. Г. Найман. Конец первой половины XX века. Раздел «Приложения». - Москва: Художественная литература, 1989. - 302 с.

${ }^{25}$ Гиленсон Б. А. [Нобелевская премия] // ЛЭС, с. 303-304.
} 
poet, the other - a foreign one. In 1953, at the second award ceremony, the prize was given to Salvatore Quasimodo, the Hermetic poet (1901-1968). Six years later, he obtained the "Nobel prize” $(1959)^{26}$.

A Welsh poet Dylan Thomas was the second laureate (1914-1953, posthumous). After that, he entered into all leading anthologies of English-language poetry (for example, Oxford anthology ${ }^{27}$ ).

This award ceremony was announced by the American journal Poetry in May 1954.The information was printed in the chronicle section ${ }^{28}$.

Giuseppe Villaroel, a member of the Organizing Committee told us about the award ceremony. The poets with publications from 1950-1953 were invited to the contest in advance. The prize was 2 million lire. This number can impress the readers, but you should remember how much lira cost in that period. By the way, after returning, Akhmatova was likely to give away the monetary part of the prize to the authorities. It was the time in the USSR.

Anna Akhmatova-Horenko was awarded the Sicilian Prize during the sixth ceremony ${ }^{29}$. The same year in the USSR, the period called "Thaw" was about to end. On October $15^{\text {th }}$ after N. S. Khrushchev's resignation, she called it a coup d'etat ${ }^{30}$. Yes, such poets as M. Svetlov, A. Voznesensky, E. Vinokurov, B. Okudzhava came out of the shadows and their books were published. But the novels by K. Simonov («Солдатами не рождаются») or O. Honchar («Тронка») were not perceived by readers as a grand-scale event compared to these authors' earlier publications.

V. Peskov («Шаги по poce») even received the Lenin Prize (like O. Honchar), but this didn't add to the scale of his book. Against this

${ }^{26}$ Quasimodo Salvatore (1901-1968), an Italian poet-hermeticist. During the World War II, he was an author of Resistance literature. Nobel Prize Laureate (1959). He published two books of poetry before the war (1930, 1936), one during the war (1944), two books after $(1947,1949)$. His book of poems (1961) was publishedin a Russian translation with a foreword by Alexei Surkov, the head of the Soviet Union of Writers. Hermeticism is a movement in Italian poetry and criticism (1920-1940s). It is characterized by maximum symbolism and associativity; minimal logical and compositional relationships between words and lines. Difficulty in perception.

(G. Ungaretti, E. Montale, S. Quasimodo) opposed to the official propaganda and literature. См.: Котрелов Н. В. Герметизм (Poesia Hermetica) // ЛЭС, с. 77.

${ }^{27}$ Dylan Thomas (1914-1953), a Welsh poet. He released three books of poetry before the war and one after the war, he wrote prose and a radio play. He was known as an innovator among critics. P. 980-986.

Thomas, Dylan. [Poems] // Poetry in English: The Anthology. - Oxford: OUP, 1987. - 1196 p. -

${ }^{28}$ [S.n.] Poetry Chronicle // Poetry. - New Jersey. - 1954. № 5. - P. 302-320. Сайт www.jstor.org. Дата обращения: 15.12.2018

${ }_{29}$ Ахматова А. А. Собрание сочинений: В 6 т. - Москва: Эллис Лак, 1998-2002; Т. 7 (дополнительный) - 2004. - С. 319.

30 Черных В. А. Летопись жизни и творчества Анны Ахматовой: 1889-1966. - Издание 3-е, исправленное и дополненное. - Москва: Издательский центр «Азбуковник», 2016. - С. 793. 
background, the scale and, so to speak, the quality of Akhmatova's poetry are doubly noticeable.

However, a decrease in the scale (or, in Shakespearean terms, "materiality" of awards) will reach the Western Europe. In 2014, the Etna Taormina Prize that - alas! - ceased to exist shortly after Akhmatova triumph, was revived under Anna Akhmatova name. And that was Larisa Vasilieva who received it in Italy. ${ }^{31}$ What for? For the series of hit documentary short stories called «Кремлёвские жёны» ...

But Eligio Jardin, Taormina mayor, will deliver a touching speech at the opening of the monument to Akhmatova in 2015. Addressing the audience, he will say: the great poetess has visited Italy for the third time.

Why did he say "the third time"? For the first time (looking back) Akhmatova came to Italy in 1912. For the second - when she received the award. For the third time, she visited the country she admired as a chesthigh monument.

\section{Companions}

A tragic poetess, a tragic person, Akhmatova survived a lot of misfortunes. Except one. Contrary to her own words («Эта женщина одна...»), she never remained alone.

Admirers, friends, sisters in misfortune, colleagues in philological studies (Pushkin studies, literary translation). Memoirists and biographers ...

There were always companions near Akhmatova.

When she didn't take a liking to them, she - quite decisively pushed them back. Just so she did not make friends with Korney Chukovsky (but befriended with his daughter for all her life). She did not get on Nadezhda Mandelstam (but was close with him). She gave due to Boris Pasternak talent (but she valued higher Mikhail Lozinsky's human and translation gift) ${ }^{32}$ ).

One way or another, in Crimea or in Kyiv, in Tsarskoye Selo or in Komarovo, in Petrograd-Leningrad or in Tashkent - everywhere Akhmatova was around people. Especially in Italy. Giancarlo Vigorelli met her in Rome (he personally sought her arrival). Akhmatova became the laureate of 1964 Etna-Taormina Prize together with Mario Lutsi, an Italian poet (1914-2005, later nominated for the Nobel Prize).

\footnotetext{
${ }^{31}$ [S.n.] ItalyAnniversaryAkhmatovaPrizeGoestoLarisaVasilieva. - Электронный ресурс. - Режим доступа: www.russkijmir.ru.

${ }^{32}$ Фёдоров А. В. Из воспоминаний и размышлений о Михаиле Леонидовиче Лозинском человеке и мастере // Багровое светило. Стихи зарубежных поэтов в переводе Михаила Лозинского. (Серия «Мастера поэтического перевода». Вып. 17.) - Москва: Прогресс, 1974. - С. 170-190.
} 
Carlo Riccio accompanied her in Rome and was the first to translate her poems into Italian. Irina Punina washer companion in travel to Italy. The delegates to the Congress of European Writers Community, Ingeborg Bachmann and Hans Richter were her guests in the hotel. A film director and poet Pierre Paolo Pazolini gave the premiere of his film The Gospel of Matthewand presented a poem to Akhmatova during the award ceremony. Vigorelli was not alone at the presidium table, Salvatore Quasimodo, Giuseppe Ungaretti and Rafael Alberti joined him.

She was travelling with both officials and poets on the "Soviet" delegation: the delegation head Aleksey Surkov, Alexander Twardovsky, Konstantin Simonov, Mikola Bazhan. And yet there were poets from all over Europe - Italians, Spanish, Finns, Portuguese, Swedes, French, Germans, Romanians, English, Yugoslavs, Hungarians, Irish, Bulgarians, Icelanders, Polish, Czechs and Slovaks ... And also photographers, journalists, film and television cameramen.

It is significant that Chaliapin's son, Fyodor Chaliapin Jr., will join her in Rome.

In addition to magnetic power to attract people, Akhmatova had another gift. Decades of parting without hope of ever meeting, parting with rare letters, the era of graves not found and addresses lost gradually developed Anna Andreevna's ability to see invisible and to hear unspoken.

From a text to a text, from a year to a year, Akhmatova the poetess is increasingly getting accompanied by shadows, dreams, ghosts and visions. Steps instead of walking. Visions instead of spectacles. Quiet airs instead of sounds.

Companions are joining her in the "dusk" of empty theater boxes. They are moving through the Summer Garden with statues - a crowd of invisible "friends and enemies"/ And each time their "absence that is present" gives the poetess an acute pain and no less acute pleasure feelings that are often much more tremulous than caused by the same characters in the "real life".

It was permissible to make fun of real "Osia" (Mandelstam) in a friendly way. Beloved Eyes, looking at Akhmatova from somewhere across the Yenisei (i.e. from the concentration camp in the Far East), exclude irony. Alexander Blok could "smile" at Akhmatova "contemptuously" from the past but she never did it at him. He had already died, she was alive. The power of the deceased is stronger. 
And in Italy? At the farewell show of the whole Akhmatova's life? From infinity distant Taurida summer, where the "wild girl" remained, to Taormina "spring in winter", where still beautiful but elderly laureate will draw her European golden ticket. But she will receive it by the "berth", to which "the death itself" was about to approach.

There are many people around the poetess there - even more than at home, especially during the last decades. In fact, it was three December weeks in Italy that Akhmatovawas living a normal life of a literary star. And the companions, along with those who are alive will also be normal but alive forever.

Today, those who are reading or carrying out research in AkhmatovaHorenko legacy know well the meaning of the word "svyatsy" (a holy calendar). But even now it is difficult to feel into that - the world that ismany century oldwhere "svyatsy" was not "a mere word", but a controller of the life.

The authors of this research have already covered the stay of Akhmatova's friend, poet Osip Mandelstam in the Crimean Alushta in August $1917^{33}$. In the poem «Золотистого мёда струя из бутылки текла...» that was written at the same period, Osip Mandelstam (like Akhmatova) mentioned some of his invisible companions: Homer Penelope waiting for her husband (although he may never return); Homeric Odyssey who came back to his homeland at last with spiritual wealth accumulated during his travel rather than with claims to the unfair fate; Homeric Argonauts who brought home a golden fleece rather than the tired curses...

And at the end of his poems Osip Mandelstam will express hope that the sad Taurida will also give a gift to all of them: those who arestateless persons and deportees. (There were no such words in that time's everyday life but the phenomenon existed.)

It's worth adding another fact of past reality that stays unnoticed today. At the same time, in the same Taurida, in the churches of Alushta, they were praying for the saints whose memory was celebrated in August 1917. Their life stories (the prayers heard them in chants or in sermons) presented not the "image" but the "pattern" to the audience. Pattern of what? How one can manage to live a life that is rough like the Crimeans

\footnotetext{
${ }^{33}$ Казарин В. П., Новикова М. А. Стихотворение О. Э. Мандельштама «Золотистого мёда струя из бутылки текла...»: (Опыты реального комментария) // Вчені записки Таврійського національного університету імені В. І. Вернадського. Серія: «Філологія. Соціальні комунікації». Т. 29 (68). № 1. - Київ: Гельветика, 2018. - С. 142-152.
} 
had in 1917. How to face death that is not less awful (such as extermination of entire families) and will not break down.

Did Akhmatova view those patters in Sicilian Taormina in 1964?

We do not have direct documentary evidence on that. However, Catholic Italy and Catholic Sicily couldn't have failed to introduce the guest from the North to their holy. And we, who know this impressive list, cannot help but notice how a lot of characters from these life stories are mysteriously associated with the personal spiritual experience of Anna Andreevna Akhmatova-Horenko.

Taormina websites and guides ${ }^{34}$ point to some of the most famous city temples that named after the saints.This is St. Nicholas Cathedral in the central square (Dom San Nikolo, 1400). It was built on the site of one of the first Taormina churches. This is a temple in the name of St. Augustine (San Agostino, also of the 15th century). It was erected in gratitude for ridding the city of the plague. This is a church in honor of the bishop and city patron Holy Martyr Pankratii (San Pancrates, II half of the 16th century). Finally, this is the church on top of Mount Taurus Our Lady of the Rock (Madonna della Rocca, 1648).

How do these saints - and their lives - relate to Akhmatova's life? St. Nicholas helped the desperate: innocently arrested, convicted, and even sentenced to death. Isn't that the fate of people from Akhmatova's inner circle? Didn't she embody them in her lyrics and Requiem?

St. Pankratius is Apostolus Peter's apprentice, ordained by him as bishop. But he did not carry out a post, but a mission, and he fulfilled it at the cost of his life and death: the pagans lured him and killed him. Probably, it was not difficult to guess their plan. But did not Pankratius think of those whom his preaching (and even more, his death) could spiritually strengthen? And did not Akhmatova think of the same thing, painfully reflecting on the Gospel Supplication for the Chalice?

Blessed Augustine was closest to people like Akhmatova. Brilliant rhetorician, philologist, philosopher. The author of a half-treatise-halfpoem in prose About the City of God and the first New European diary Confessions. All this is a characteristic of Augustine in "worldly" terms. In spiritual terms, his Heavenly city is a real vision, his confession is a real confrontation of a person with his conscience.

\footnotetext{
${ }^{34}$ https://www.britannica.com/place/Taormina; https://ru.wikipedia.org/wiki/Taормина. The images used in our article (landscapes of Taormina, a bust of A. A. Akhmatova-Horenko, awarding the Etna-Taormina Prize, etc.), see the following sites: https://www.britannica.com/place/Taormina; https://ru.wikipedia.org/ wiki/Таормина; http://www.bfrz.ru/?mod=static\&id=655; https://www.russianartandculture.com/news-annaakhmatovas-monument-opens-in-sicily.
} 
Is this experience alien to Akhmatova? "Serial" arrests, "enhanced interrogations" and the elimination of new martyrs of the twentieth century, captured in Akhmatova's memoirs and Requiem, are completely superimposed on the "serial" torture and elimination of the first martyrsChristians of the first centuries of our era. So, contemporaries of St. Pankratia in "serial" martyrdom were St. Markell, Bishop of Sicily (Sicelian), and St. Filagrius, Bishop of Cyprus.

All the three - the 1st century AD; all the three have the same day of remembrance - February 9, according to the Julian Calendar. The triple of the Mediterranean holy martyrs (all of them are Apostle Peter's disciples) have a high spirit and tragic fate in common with Ukrainian neoclassical poets of the twentieth century from Kyiv, three of whom also died - on Solovki and in Kolyma.

When presenting the Sicilian Prize, Akhmatova chose verses about the Muse dictating the pages of Hell for Dante's response. But Dante's Hell is not a literary "description", let it be brilliant. It is a document of real human repentance. The real experience of hellish horrors. If you like, this is the medieval ArchipelagoGULAG - only one where there are no innocents ... Is that why Alexander Twardovsky, the son of a peasant (and repress) Belarusian family, did not listen to Akhmatova's lines about Dante like they listen to the texts of "belles-lettres"?..

The highest possible Akhmatova's meeting on Sicilian land, this is a meeting with Via Dolorosa, the Way of the Cross, and with Madonna della Rocca, Our Lady of the Rock. Tired, suffering from heart disease, Anna Andreevna will refuse even from a tour of Etruscan places in Rome and from a trip to the memorial house of Giacomo Leopadi, whose verses she translated. She could hardly walk on Taormina Via Dolorosa. But this path, this temple, this Mother, who gave the Son to death for the salvation of people, themselves appeared before her.

\section{Colors of destiny}

As we recall, one of the spiritual mentors of Akhmatova in Sicily St. Augustine. No wonder his name was given to the temple in Taormina, on Akhmatova's route. But Augustine himself, for centuries, has been, so to speak, the "holy of the intellectual society".

The life of St. Augustine is not the life of a "ready saint", nor even a "ready Christian". He personally went through many trials close to subsequent intellectuals. Ancient philosophy, ancient heroics, ancient art have long blinded and fascinated young Augustine. Similarly, the 
brilliance and risk of literary, philosophical, religious searches of the Silver Age for decades seduced Akhmatova.

The fact that the theater fan of this century is broken, and its smell is not only sweet, but also terrible, she realized only in A Poem Without a Hero and further. The austerity of late Augustine is akin to the austerity and suffering of Akhmatova's Requiem. That is why both Augustine's City of God and Augustine's Confession in the world of Akhmatova are read as a kind of supertext about "complete death in earnest” (B. Pasternak). But after all, about complete salvation seriously! In these texts, it is not the rhetoric of the brilliant orbit that arises, but the real visions of the real suffering confessor. This happens to the Akhmatova's Crimea.

Four colors paint both Akhmatova's Crimea of 1916, and Akhmatova's Rome of the year 1964. These are colors red (scarlet) and gold colors of passion and power, regality and sacrifice, bleeding momentary and overcoming eternity. And next to it is blackness (shadow, grief, loss, death) and whiteness (a blank sheet of creative ideas, but also snow, gray hair, also loss, also death).

There is Bakhchisaray Akhmatova's vision ("Вновь подарен мне дремотой...”, 1916). In it, Akhmatova declares that she sees through this slumber the "golden Bakhchisaray" of her last Crimean meeting with one of the main lyrical heroes of her "silver" youth - Nikolai Nedobrovo. Their week in Bakhchisaray is described as sacred action and magic, when in the former capital of the Khanate, the capital of Crimea the eternal Southeast - the meeting-farewell of two lasts forever, in the presence of the third - Queen of Autumn.

This golden vision illuminates the whole day of the Bakhchisaray cycle: the "motley" day, and the crimson sunset, and the impending "kingdom of shadow", where not only the "comforting" friend, but also the whole young past of the "legendary" century and its poets: the poet men (N.N.) and the female poet (Akhmatova) ...

Almost 50 years later, in the 1964 inscription on the book of his poems, presented to the young translator Akhmatova. and her guide to Rome, Carlo Riccio, Akhmatova will call December 6 (according to the old style - the day of St. Nicholas "winter", according to the new style - the day of St. Alexander Nevsky, the patron saint of St. Petersburg) - "golden day".

Before us is not just a color coincidence with Bakhchisaray. “Golden” Roman day also embraces Akhmatova's standing on St. Peter's Square, in a crowd of pilgrims, and the midday bell ringing of the 
cathedral, and the tears of shocked Akhmatova, noticed by her guide. And even deeper - other compositional parallels are hidden in the main "golden" epithet. A young friend, poet Nikolai Nedobrovo in Bakhchisarai - a young friend, poet and translator Carlo Riccio in Rome.

The ecstasy of Bakhchisaray night ("starry paradise") is the ecstasy of Roman noon. Farewell forever to paradise Bakhchisaray and his "comforting" companion - farewell forever to paradise Rome and his "sweet" escort. (Akhmatova did understood: both in age and in the attitude of the "Soviet" government-supervised, she is unlikely to go to Italy again).

Let us now return to the other two colorates, which have so far remained outside the brackets: scarlet and white. The scarlet ("pinkscarlet”) color permeates - directly or indirectly - the entire Bakhchisaray confession-vision of Akhmatova. His and Her conversations take place at the "water" bordered by a "motley" wall. The reconstruction of the Bakhchisaray routes of this pair indicates: "brooding water", most likely, is a pool on the territory of the Khan's palace complex.

And the "variegation" around is (taking into account the autumn) grapes winding along the wall, whose leaves have acquired all shades of red. The American poet Edwin Robinson (1869-1935) in his favorite poem by US President Theodore Roosevelt (1858-1919) Luke Havergol - "grapes crimson rings howls" and rustles his "dead foliage". Akhmatova's red foliage - not in the palace, but on the stairs of the city is just not dead.

These are the leaves of the Crimean tannin and dyeing plant - sumac. They are collected and brought in the hem (like Crimean Tatars) Autumn itself. It brings - and showers with them the stairs, "where you and I said goodbye”. And behind the scenes, in the mind of the reader, Akhmatova's "red maple leaf" appeared in the Bible on the hymn of love - Song of Songs.

It is clear then why in Italian notes Akhmatova mentions the "pinkred” sunset, which accompanied her when leaving Bakhchisaray (1916), against the background of the same color of the sunset that met her at the entrance to Rome (1964). The coincidence evoked in memory of the died friend Nikolai Nedobrovo, and not just him. We believe, on the basis of all Akhmatova's color vision, that this scarlet palette speaks not only about passion and the separation of the two. This, in addition, is the rushing memory of parting with the Crimea. The Crimea as part of the biography of several generations of the Horenko family, and even part of the entire Silver Age, both the "calendar" and the "legendary". 
It seems that the stay in Sicily, the "Sicilian Vespers" (after the opera Giuseppe Verdi), turned out to be "a Sicilian leave” for Akhmatova. By the presence nearby again, but also by letting go into the world of a whole host of relatives and friends, lovers and "comrades in the art of marvelous".

In the 1960s, in letters to Anatoly Neumann from the hospital, after another, each time more severe heart attack, Akhmatova speaks not of death, but of the life after death. About how they will continue to live together, singing birdies in a cage (the words of King Lear, addressed to the dead Cordelia). She, this Death-Post-Death, - invisibly, but clearly, in color associations - accompanies the short - jubilant and weeping - Italian journey of the poet: «А как музыка зазвучала / И очнулась вокруг зима, / Стало ясно, что у причала / Государыня-смерть сама» ${ }^{35}$.

Together with Her, the "winter" Tsarskoye Selo Pushkin enters the Italian world of Akhmatova: Akhmatova with another character in her own biography. And - farewell to yet another "silver" love, which Akhmatova devoted the largest number of "targeted" verses: 17 in the collection White Pack and 14 in the collection Plantain. This plot "leads" Akhmatova's whiteness.

Pushkin set the color code in the story The Captain's Daughter (chapter The Court). The landscape of Tsarskoye Selo begins with clear morning, with the rising sun, from the peaks of lindens, «пожелтевших уже под свежим дыханием осени». (Note: there is yellowness here, there is no gold; compare «B багрец и в золото одетые леса» by the same Pushkin, also autumn, but in a different text, Autumn). Further in the story is drawn a shining lake (without colorings); further on, swans that «важно выплывали» (again regal, and again without a colorative, although the whiteness of swans is already directly implied). But here comes the «белая собачка» and - in tone with her - the lady «в белом утреннем платье».

It follows the famous dialogue of the Lady in White (Empress Catherine II incognito) with Masha Mironova. There is a reading of the letter followed by the dialogue which contains Masha's petition for clemency of the groom (white paper!), and the denouement.

The last time (letter to letter!) the "handwritten letter of Catherine II" flashed "behind the glass and in the frame" of Grinev's house. The letter contains "praises on Masha's mind and heart”, but there is not a word

${ }^{35}$ Ахматова А. А. Собрание сочинений: В 6 т. - Москва: Эллис Лак, 1998-2002; Т. 7 (дополнительный) - 2004. - Т. 2. - 238. 
about how the Empress "arranged" the "wealth" promised to Masha? But no way. The descendants of the Grinevs live in the outbuilding, in a remote village, "owned by ten landowners". The whiteness of great power mercy turned out to be an empty place. This place was predicted in advance by the "long row of empty, magnificent rooms" of the imperial palace, through which the camera-footman once led "frightened" Masha.

With whom is whiteness connected in Akhmatova's personal confession - lyric cycle? White becomes the theme color in the plot of Anna Akhmatova and Boris Anrep.

Whiteness even encroaches on acrostics made up of the name and surname of B.A.: «С покатых гор ползут снега, / А я белей, чем снег <..>». Ту же белизну встречаем в стихах о Духовом дне, когда Героиня ожидает Друга: «За окном крылами веет / Белый, белый Духов день <..> / Помоги моей тревоге, / Белый, белый Духов день!» ${ }^{36}$.

White in this lyric cycle is not the color of emptiness, but the color of fullness. This is the presence of Light, uniting all colors; the Spirit that embraces all the senses, raising with its wings them to the height of a sacred festivity ...

Significantly, in this "white cycle" the confession of love - again and again - sprouts a vision of Crimea.

The verses of the Spirit Day reflected the Chersones chronicle. Akhmatova recalled: "В Херсонесе три года ждала от него письма. Три года каждый день, по жаре, за несколько вёрст ходила на почту, и письма так и не получила» ${ }^{37}$. Poems narrate it this way: «Bcë мне дальний берег снится, / Камни, башни и песок. // На одну из этих башен / Я взойду, встречая свет...» ${ }^{38}$. The Chersones character of this landscape cannot be overlooked and noted. The poem is dated 1916 - it is almost synchronous to the Bakhchisaray poem, differing in local realities, but not in the common Crimean context.

That is how the "color square” of Akhmatova developed. All four key colors have become centers that attract characters, plots, genres - even texts of different genres: oral Akhmatova's stories - "records", written notes, poems, published and / or put in a box. In a Sicilian-Italian context, some of these colors will be transformed. White will go into subtext: the

\footnotetext{
${ }^{36}$ Ахматова А. А. Собрание сочинений: В 6 т. - Москва: Эллис Лак, 1998-2002; Т. 7 (дополнительный) - 2004. - Т. 1. - С. 265.

37 Лукницкий П. Н. Acumiana. Встречи с Анной Ахматовой. В 2 тт. - Paris: YMCA-PRESS, 1991-1997. - T. 1. - С. 21.

${ }^{38}$ АхматоваА. А. Собрание сочинений: В 6 т. - Москва: Эллис Лак, 1998-2002; Т. 7 (дополнительный) - 2004. - Т. 1. - С. 265.
} 
theme of the light stone of statues, temples, etc. Black will be replaced by the theme of joyful nights (with guests, trips, recitation of verses). But the dominant colors will still remain on duty on the outskirts of Akhmatova's Taormino-Roman landscapes. Their admission to her poems and her biography will still happen - and will happen again soon.

\section{CONCLUSIONS}

Having collected - or reconstructed - the details of Anna Andreyevna Akhmatova-Horenko's Sicilian journey, from provable details to only possible details, the researchers also think about the goals of their future work. And the work ahead (we are convinced) is not just large quantitatively, but also being carried out on a new scale, using various, including new, strategies.

1. At the factual level, the background of this trip is to be filled, both from the "Soviet" and from the Italian side. It includes dozens (if not hundreds) of people, addresses and routes; political, cultural, religious calendars; texts not only directly related to Akhmatova's "December spring" but also making up its wide context.

2. At the symbolic level, it is important to understand what significance had - or could have had - this supposedly "small” episode. Here, the movement from a single biography to a biography of a whole era (and not one), a whole region and a country (and not one), a whole generation (and not one) can be promising. The answers to these questions are not reducible to not only the external chronicle, but also to the evidence and reminiscences of purely "literary".

So, we sought to find objective connections between the two "preserves of the soul" of Akhmatova: Italy and Crimea. Behind them, however, were connections not only within the framework of Akhmatova's trip of 1964, but for centuries and millennia. For other writers, such an analytic scale would be excessive. For Akhmatova's fate, a smaller scale would be insufficient.

3. Akhmatova's life and poetry still full of white spots, and there are many reasons for this. We give only one illustration. On a 1964 trip Akhmatova was surrounded by a benevolent and even admired audience. For all that, she didn't call by the names of her dear "flying shadows", she didn't refer to living, close friends to her. We believe that the writers and journalists of Italy, who went through the severe school of their 1930s-1940s, correctly guessed the reasons for such an expressive silence. 
4. From here comes the general task of new Akhmatology. It consists nevertheless (we repeat) not so much in closing the gaps, but in opening the scales. One of memoirists of Akhmatova, Sir Isaiah Burlin, called these scales "cosmic". We proposed the term "metaphysical”. The bottom line is the same. Studying Akhmatova (and figures typologically similar to her), we study not just literature, but Super Literature. And this must be practically reckoned with.

Крым-Киев, 2017-2019

\section{SUMMARY}

The paper offers and argues a new look on the Italian and Crimean context of Anna Akhmatova-Horenko's life and poetry (1889-1966). A special emphasis is laid on Akhmatova's trip to Sicily (1964), where the poet received the "Etna-Taormina" literary prize from the European Community of Writers. This episode is constantly mentioned in Akhmatova's new biographies, but so far it has not been considered an important event in her emotional and spiritual life. Akhmatova's Sicilian events and impressions have never been put parallel with the Crimean ones. Meanwhile, a close analysis reveals many - previously ignored intersections among the chronotope, cultural and religious references and symbols of Sicily and Crimea. Biographical and poetological approaches prove how significant this double - Crimean-Italian - was for Akhmatova's human and art experience.

\section{REFERENCES}

1. Казарин В. П., Новикова М. А. «... Ровно десять лет ходила / Под наганом...»: (А. А. Ахматова-Горенко и сэр Исайя Бёрлин) // Вчені записки Таврійського національного університету імені В. I. Вернадського. Серія: «Філологія. Соціальні комунікації». Т. 29 (68). № 2. - Київ: Гельветика, 2018. - С. 201-213.

2. Пунина И. Н. Анна Ахматова в Италии // La Pietroburgodi Anna Achmatova. - Bologna: GrafisEdizion, 1996. - P. 54-64.

3. [Б.а.] Русские писатели - лауреаты итальянских литературных премий. [Электронный ресурс]. - Режим доступа: https://www.bfrz.ru/ ?mod=static\&id=655.

4. Many of the writers who met Akhmatova in Italy and / or translating her poems were participants in the Resistance during the Second World War. See: Потапова 3. М. Литература Сопротивления: Италия // Литературный энциклопедический словарь (далее сокр. ЛЭС). - Москва: Советская энциклопедия, 1987. - С. 412. 
5. For more details, seе Казарин В. П., Новикова М. А. Анна Ахматова и Херсонес: что сказали поэту «смуглые главы» храма? // Сайт «КРУ УНБ имени И. Я. Франко» (franco.crimea.ua). 02.06.2014.

6. [Б.а.] Taurus //Словарь классических древностей по Любкеру. Пер. с немецкого. Под ред. Ф. Зелинского и др. СПб., 1885. - 1552 с. С. 1346. (Далее сокращенно: Любкер).

7. [Б.а.] Tauri // Любкер, с. 1345.

8. [Б.а.] Tauropolos, Arthemis // Любкер, с. 164.

9. [Б.а.] Tauromenium // Любкер, с. 1346.

10. About Taormina, see https://www.britannica.com/place/ Taormina; https://ru.wikipedia.org/wiki/Tаормина.

11. Новикова М. А. Пушкинский космос: Языческая и христианская традиции в творчестве Пушкина (Серия «Пушкин в XX веке». Вып. 1.). - Москва: Наследие, 1995. - 353 с.

12. Отин Е. С. Топонимия приазовских греков (историкоэтимологический словарь географических названий): Издание 2-е, исправленное и дополненное - Донецк: ООО «Юг-Восток Лтд.», 2002. -212 c.

13. Холл Джеймс. Лестница // Джеймс Холл. Словарь сюжетов и символов в искусстве. Перевод с английского и вступительная статья Александра Майкапара. - Москва: Крон-Пресс, 1999. - 656 с.

14. [Б.а.] Naxos // Любкер, с. 909, 1245.

15. Багровое светило. Стихи зарубежных поэтов в переводе Михаила Лозинского. (Серия «Мастера поэтического перевода». Вып. 17). - Москва: Прогресс, 1974. - 216 с. - С. 211.

16. Photographic materials used in our article (landscapes of Taormina, bust of A. A. Akhmatova-Horenko, awarding her the EtnaTaormina Prize, etc.) see on websites https://www.britannica.com/place/ Taormina; https://ru.wikipedia.org/wiki/Tаормина; http://www.bfrz.ru/ ?mod=static\&id=655; https://www.russianartandculture.com/news-annaakhmatovas-monument-opens-in-sicily.

17. About Gaspra and Charax, see [Б.а.] Всё о Крыме: Справочноинформационное издание / Под общ. ред. Д. В. Омельчука. Харьков: Каравелла, 1999. - 400 с.

18. Галиченко А. А. Алупка: Дворец и парк . - Киев: Мистецтво, 1992. - $240 \mathrm{c}$.

19. Крым: Православные святыни: Путеводитель / Составитель Е. М. Литвинова. - Симферополь: Рубин, 2003. - 384 с. 
20. Казарин В. П., Новикова М. А. Стихотворение А. А. Ахматовой «Вновь подарен мне дремотой...»: (Опыты реального и поэтологического комментирования). Публикация 1 // Анна Ахматова: эпоха, судьба, творчество: Крымский Ахматовский научный сборник. Выпуск 10. - Симферополь: Крымский Архив, 2012. - С. 60-72; Публикация 2 // Сайт «Анна Ахматова: «Ты выдумал меня...»» (akhmatova.org). - 08.05.2013; Публикация 3 // Сайт «Бахчисарайский историко-культурный заповедник» (bikz.org), - 06.06.2013.

21. Найман А. Г. Рассказы об Анне Ахматовой // А. Г. Найман. Конец первой половины XX века. Раздел «Приложения». - Москва: Художественная литература, 1989. - 302 с.

22. Гиленсон Б. А. [Нобелевская премия] // ЛЭС, с. 303.

23. Премии литературные / Зарубежный раздел // ЛЭС, c. $303-304$.

24. [S.n.] Poetry Chronicle // Poetry. - New Jersey. - 1954. № 5. P. 302-320.

25. Сайт www.jstor.org. - Дата обращения: 15.12.2018.

26. Котрелов Н. В. Герметизм (Poesiaermetica) // ЛЭС, с. 77.

27. Thomas, Dylan. [Poems] // Poetry in English: The Anthology. Oxford: OUP, 1987. - 1196 p. - P. 980-986.

28. Черных В. А. Летопись жизни и творчества Анны Ахматовой: 1889-1966. - Издание 3-е, исправленное и дополненное.Москва: Издательский центр «Азбуковник», 2016. - 944 с., ил.

29. [S.n.] Italy Anniversary Akhmatova Prize Goes to Larisa Vasilieva. - Электронныйресурс. - Режимдоступа: www.russkijmir.ru.

30. Фёдоров А. В. Из воспоминаний и размышлений о Михаиле Леонидовиче Лозинском - человеке и мастере // Багровое светило. Стихи зарубежных поэтов в переводе Михаила Лозинского. (Серия «Мастера поэтического перевода». Вып. 17.) - Москва: Прогресс, 1974. $-218 \mathrm{c}$.

31. Казарин В. П., Новикова М. А. Стихотворение О. Э. Мандельштама «Золотистого мёда струя из бутылки текла...»: (Опыты реального комментария) // Вчені записки Таврійського національного університету імені В. І. Вернадського. Серія: «Філологія. Соціальнікомунікації». Т. 29 (68). № 1. - Київ: Гельветика, 2018. - C. 142-152.

32. [Б.а.] Мария, Богородица // Полная популярная библейская энциклопедия. В 2 кн. Кн. 1. [Репринт издания 1891 г.]. - Москва: Издательство СП МСИ и др., 1990. - С. 454-456. 
33. Аверинцев С. С. Николай-чудотворец // София-Логос: Словарь. - Киев: Дух и литера, 2000, - С. 139-140.

34. Аверинцев С. С. Августин, Аврелий // София-Логос: Словарь. - Киев: Дух и литера, 2000. - С. 15-16.

35. [Б.а.] Августин Блаженный, архиеп. Гиппонский (353-430 гг.) // Полный православный богословский энциклопедический словарь. Т. 1. [Репринт]. - Москва: АО «Возрождение», 1992. - Стлб. 22-24.

36. Бычков В.В. Эстетика Аврелия Августина. М.: Наука, 1984.

37. [Б.а.] Панкратий Тавроменийский, священномученик // Православный церковный календарь. 2009. [Мученики]. - Москва: ИздательскийСоветРПЦ, 2008. - С. 26.

38. Robinson, Edwin Arlington (1869-1935) // Poetry in English: An Anthology. - New York, Oxford: OUP, 1987. - 1196 p. - P. 794-95. [Об участии президента США Теодора Рузвельта в судьбе поэта см. с. 794. Русский перевод стихотворения сделан М. А. Новиковой.]

39. Ахматова А. А. Собрание сочинений: В 6 т. - Москва: Эллис Лак, 1998-2002; Т. 7 (дополнительный) - 2004.

40. Лукницкий П. Н. Acumiana. Встречи с Анной Ахматовой. B 2 тт. - Paris: YMCA-PRESS, 1991-1997.

41. Фарджен А. Приключения русского художника: Биография Бориса Анрепа. - СПб.: Издательство журнала «Звезда», 2003. C. 286, 299.

\section{Information about the author:}

Kazarin V. P., Doctor of Philology, Professor, Acting Rector,

V. I. Vernadsky Taurida National University 31, J. McCain str., Kyiv, 01042, Ukraine 